УДК 633.844:631.543:631.86 (477.7)

DOI https://doi.org/10.32848/agrar.innov.2021.10.8

\title{
ФОРМУВАННЯ КОМПЛЕКСУ БІОМЕТРИЧНИХ, СТРУКТУРНИХ І ПРОДУКТИВНИХ ПОКАЗНИКІВ ГІРЧИЦІ САРЕПТСЬКОЇ ЗАЛЕЖНО ВІД НОРМИ ВИСІВУ ТА РІВНЯ БІОЛОГІЗАЦІЇ ТЕХНОЛОГІЇ ВИРОЩУВАННЯ КУЛЬТУРИ В УМОВАХ ПІВДЕННОГО СТЕПУ
}

\author{
ЖУЙкОВ О.Г. - доктор сільськогосподарських наук, професор \\ https://orcid.org/0000-0002-5762-7934 \\ Херсонський державний аграрно-економічний університет \\ ХОдОС Т.А. - аспірантка II року навчання \\ https://orcid.org/0000-0002-7744-1424 \\ Херсонський державний аграрно-економічний університет
}

\begin{abstract}
Постановка проблеми. Сучасний екологічний стан абсолютної більшості вітчизняних агроландшафтів, спричинений нераціональним застосуванням мінеральних добрив та синтетичних 33Р, не може не викликати занепокоєння як наукової спільноти, так і прогресивної частини сільгосптоваровиробників [1; 2]. Водночас трендом натепер є мінімізація розхідної частини у структурі собівартості будь-якої культури, що дозволяє виробникові успішно конкурувати на внутрішньому та зовнішньому ринках агросировини. Отже, на наш погляд, майже безальтернативним у світлі вищенаведеного виглядає більш інтенсивне залучення до практики українського агровиробництва біологізованих і органічних технологій вирощування с.-г. культур, спроможних водночас забезпечити як суттєву економію матеріально-технічних ресурсів (до 30-60\% у структурі собівартості, передусім завдяки зменшенню або цілковитої відмови від використання мінеральних туків та синтетичних пестицидів), так і радикально зменшити пестицидний пресинг на біоту агроценозу (ґрунтова мікрофлора, корисні ентомофаги, культурна рослина) [3].
\end{abstract}

Аналіз останніх досліджень і публікацій. Аналіз сучасного вітчизняного і закордонного наукового продукту дає можливість зробити висновок про вкрай недостатній рівень дослідженості даної наукової проблеми в аспекті культури гірчиці сарептської, технологія вирощування якої у більшості господарств Степу й інших агрокліматичних зон залишається відверто архаїчною [4]. Варто додати, що в номенклатурі фірм - виробників органічних добрив і засобів захисту рослин, рекомендованих до застосування в біологізованих і органічних технологіях вирощування польових культур, зокрема олійних, немає конкретики щодо їх використання саме на посівах сизої гірчиці (норми, дози, кратність, умови застосування), а той нечисленний досвід, що відображений у працях науковців і практиці товаровиробників має, відверто кажучи, фрагментарний, а іноді і суперечливий характер [5]. Єдине, на чому сходяться у спільній думці як учені, так і господарники, це те, що за мінімізації застосування хімічних 33Р варто збільшувати норму висіву культури з розрахунку на більш інтенсивне пошкодження рослин фрітофагами і збудниками хвороб, проте відпрацьованих алгоритмів, які б ураховували агрокліматичні умови зони, ступень біологізації технології вирощування, відверто бракує [6]. І якщо підкрі- пленої науковими результатами інформації стосовно екологічної адаптації вирощування гірчиці сарептської (залучення до технології окремих елементів або цілих ланок біологізації) останнім часом стає все більше, то проблема отримання врожаю культури саме органічного статусу і досі залишається майже не дослідженим питанням [6].

Мета. Метою наукового дослідження було встановлення впливу на комплекс біометричних (висота рослин, площа асиміляційної поверхні, листковий індекс агрофітоценозу), структурних (елементи пробного снопу, показник $M_{1000}$ ) і продуктивних ознак (урожайність кондиційного насіння, вміст у насінні сирого жиру й ефірної олії) залежно від норми висіву культури та ступеня біологізації технології вирощування культури.

Матеріали та методика досліджень. Реалізація поставленої мети здійснювалася шляхом закладання польового двофракторного досліду і проведенням комплексу спостережень і лабораторних досліджень. Фактор А (технологія вирощування культури) був представлений варіантами традиційної зональної технології вирощування гірчиці; біологізованою технологією (відмова від мінеральних добрив і заміна їх на органічні препарати) та органічною (заміна мінеральних добрив і синтетичних 33Р на органічні препарати). Фактор В являв собою різні норми висіву культури (від 2,0 до 3,0 млн шт. схожих насінин на 1 га з інтервалом 0,5 млн). У досліді висівався сорт гірчиці Пріма селекції Інституту олійних культур Національної академії аграрних наук. Повторність досліду чотирикратна, загальна площа дослідної ділянки становила 0,9 га, загальна площа

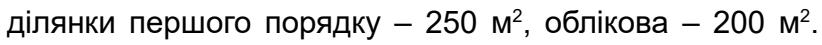
Ділянки в досліді розміщувалися методом розщеплених ділянок із частковою рендомізацією. Висоту рослин досліджували шляхом виміру мірною лінійкою на 10 типових рослинах у кожній повторності. Площа листкової поверхні культури визначалася способом висічок за методикою А.А. Нечипорович. Для визначення структури врожаю і хімічного аналізу насіння гірчиці з кожного варіанта досліду відбирали по два модельні снопи, які включали в себе типові для варіанта рослини і які висушували до повітряно-сухого стану. Для визначення маси 1000 насінин відбирали дві наважки по 500 насінин і зважували з точністю до 10,00 мг на кожному варіанті у триразовій повторності. У лабораторних умо- 
вах визначали хімічний аналіз гірчичного насіння: сирий жир - за методом Сокслета, шляхом екстрагування діхлоретаном, ефірну олію - методом додаткового екстрагування селективним розчинником (петролейний ефір). Облік урожаю насіння гірчиці проводили методом суцільного збирання. Дані врожаю насіння приводили до стандартної вологості (10\%) і стовідсоткової чистоти. Урожайні дані піддавали агрономічній оцінці та статистичному обробітку методом дисперсійного, кореляційного та регресійного аналізів.

Результати досліджень. Дослідженнями встановлено, що показник середньої висоти рослин культури у фазу повного цвітіння залежав як від норми висіву, так і від рівня біологізації технології вирощування. У досліді відмічена тенденція, згідно з якою висота рослин істотно зменшувалася зі збільшенням норми висіву, що спостерігалося на тлі всіх варіантів технології вирощування культури. Що стосується залежності даного показника від рівня біологізації технології вирощування, то мінімальних значень висота рослин культури набула за традиційної інтенсивної технології вирощування, заміна мінеральних добрив органічними комплексами зумовила зростання висоти в середньому на $6,1 \mathrm{~cm}$, а цілковитий перехід у технології вирощування на органічні добрива й органічні 33Р істотного впливу на даний показник не мав (у середньому 85,8 см проти 87,0 см) (табл. 1).

Показник облистяності (маса листків із 10 рослин) також характеризувався аналогічною залежністю від факторів, що вивчалися в досліді: із зростанням норми висіву культури маса листків на рослині зменшувалася, а максимальних значень цей показник набув за варіантом біологізованої технології вирощування (у середньому становив 13,2 г/рослину), за органічної - 12,4 г, а за традиційної - 10,5 г. Дещо іншим виявився за результатами наших досліджень характер залежності площі асиміляційного апарату гірчиці сарептської від факторів, що вивчалися в досліді. Так, за всіма варіантами технології вирощування зі збільшенням норми висіву від 2,0 до 2,5 млн шт./га цей показник істотно зростав, а з подальшим зростанням норми висіву до 3,0 млн шт./га зменшувався. Особливо стрімким зменшення листкового індексу зі збільшенням норми висіву культури виявилося за варіантом традиційної інтенсивної технології вирощування. У середньому за фактором В на 1 га посіву за інтенсивною технологією формувалася площа асиміляційного апарату на рівні 8,7 тис. м²; за біологізованою - 11,2 тис. м²; за органічною - 10,5 тис. м², що свідчить про більш сприятливі умови для продукційного процесу.

Стосовно показників структури врожаю культури нами зроблений висновок, що впродовж другого періоду вегетації («цвітіння - повна стиглість насіння») рослини гірчиці сизої продовжували збільшувати лінійні розміри, хоча інтенсивність середньодобових приростів була істотно меншою. Залежність висоти рослин від факторів досліду залишилася аналогічною: із збільшенням норми висіву цей показник зменшувався (від 4,5 до 7,9 см), а застосування окремих елементів біологізації, як і цілковитий перехід на органічні принципи вирощування, зумовлювало зростання висоти рослин культури порівняно із традиційною технологією на 3,5-5,1 см (табл. 2).

Аналогічним був і характер залежності решти елементів пробного снопу культури від фракторів, що вивчалися: збільшення норми висіву культури від 2,0 до 3,0 млн шт./га зумовлювало зменшення показника кількості плодових гілок із 4,4 до 2,9 шт., кількості стручків - із 65,4 до 31,5 шт., показника $M_{1000}$ - із 3,5 до 3,0 г, насіннєвої продуктивності однієї рослини - 31,7 до 1,0 г (за традиційною технологією). За біологізованою технологією вирощування гірчиці залежність була схожою: із збільшенням норми висіву кількість плодових гілок зменшувалася із 4,8 до 3,1 шт.; кількість стручків - із 77,2 до 39,0 шт.; показник $M_{1000}$ - із 3,8 до 3,4 г, а продуктивність однієї рослини - із 2,0 до 1,4 г. Цілковита відмова від добрив та 33Р штучного походження (органічна технологія вирощування) на тлі зростання норми висіву культури характеризувалася зменшенням зазначених показників із 4,9 до 3,3 шт., з 80,1 до 37,8 шт., із 3,9 до 3,3 г та із 2,2 до 1,2 г відповідно, що не могло не позначитися на значенні підсумкового показника, за яким оцінюється ефективність того чи того агроприйому, - урожайності кондиційного насіння (табл. 3).

Оптимальною нормою висіву за всіма варіантами технології вирощування культури визнана норма

Таблиця 1

Основні біометричні показники гірчиці сарептської залежно від норми висіву та рівня біологізації технології вирощування у фазу повного цвітіння (2020-2021 рр.)

\begin{tabular}{|c|c|c|c|c|c|}
\hline $\begin{array}{c}\text { Технологія } \\
\text { вирощування } \\
\text { (фактор A) }\end{array}$ & $\begin{array}{c}\text { Норма висіву, } \\
\text { млн шт./гa } \\
\text { (фактор В) }\end{array}$ & $\begin{array}{c}\text { Висота рослин, } \\
\mathbf{~ с м}\end{array}$ & $\begin{array}{c}\text { Маса листків із } \\
\mathbf{1 0} \text { рослин, } \mathbf{~}\end{array}$ & $\begin{array}{c}\text { Площа листко- } \\
\text { вого апарату, } \\
\text { м/ra }\end{array}$ & $\begin{array}{c}\text { Листковий індекс } \\
\text { посіву }\end{array}$ \\
\hline \multirow{2}{*}{$\begin{array}{c}\text { Традиційна } \\
\text { (інтенсивна) }\end{array}$} & 2,0 & 82,9 & 119,8 & 80784 & 8,1 \\
\cline { 2 - 6 } & 2,5 & 81,5 & 107,0 & 109232 & 10,9 \\
\hline \multirow{3}{*}{ Біологізована } & 3,0 & 78,4 & 88,1 & 72012 & 7,2 \\
\cline { 2 - 6 } & 2,0 & 89,5 & 154,4 & 94518 & 9,5 \\
\hline \multirow{2}{*}{ Органічна } & 2,5 & 88,7 & 131,2 & 124832 & 12,5 \\
\cline { 2 - 6 } & 3,0 & 82,8 & 111,0 & 115606 & 11,5 \\
\cline { 2 - 6 } & 2,0 & 88,4 & 145,6 & 95232 & 9,5 \\
\hline
\end{tabular}


Структурні показники врожаю гірчиці сарептської залежно від норми висіву

Таблиця 2 та рівня біологізації технології вирощування (2020-2021 рр.)

\begin{tabular}{|c|c|c|c|c|c|c|}
\hline $\begin{array}{c}\text { Технологія вирощу- } \\
\text { вання (фактор А) }\end{array}$ & $\begin{array}{l}\text { Норма висіву, } \\
\text { млн. шт./га } \\
\text { (фактор В) }\end{array}$ & $\begin{array}{c}\text { Висота рослин } \\
\text { у фразу повної } \\
\text { стиглості, см }\end{array}$ & $\begin{array}{c}\text { Кількість } \\
\text { плодових гілок } \\
\text { І порядку } \\
\text { на рослині, шт. }\end{array}$ & $\begin{array}{c}\text { Кількість } \\
\text { стручків на } \\
\text { рослині, шт. }\end{array}$ & $M_{1000}, \mathbf{r}$ & $\begin{array}{c}\text { Маса насіння } \\
\text { з однієї рос- } \\
\text { лини, г }\end{array}$ \\
\hline \multirow{3}{*}{$\begin{array}{l}\text { Традиційна } \\
\text { (інтенсивна) }\end{array}$} & 2,0 & 150,5 & 4,4 & 65,4 & 3,5 & 1,7 \\
\hline & 2,5 & 147,0 & 3,0 & 40,7 & 3,3 & 1,4 \\
\hline & 3,0 & 142,4 & 2,9 & 31,5 & 3,0 & 1,0 \\
\hline \multirow{3}{*}{ Біологізована } & 2,0 & 155,9 & 4,8 & 77,2 & 3,8 & 2,0 \\
\hline & 2,5 & 151,2 & 3,4 & 55,1 & 3,7 & 1,8 \\
\hline & 3,0 & 147,7 & 3,1 & 39,0 & 3,4 & 1,4 \\
\hline \multirow{3}{*}{ Органічна } & 2,0 & 152,9 & 4,9 & 80,1 & 3,9 & 2,2 \\
\hline & 2,5 & 150,0 & 3,7 & 59,6 & 3,7 & 1,7 \\
\hline & 3,0 & 146,7 & 3,3 & 37,8 & 3,3 & 1,2 \\
\hline
\end{tabular}

Таблиця 3

Урожайність кондиційного насіння гірчиці сарептської залежно від норми висіву та рівня біологізації технології вирощування (2020-2021 рр.)

\begin{tabular}{|c|c|c|}
\hline Технологія вирощування (фактор А) & Норма висіву, млн шт./га (фактор В) & $\begin{array}{c}\text { Урожайність кондиційного насіння, } \\
\text { т/га }\end{array}$ \\
\hline \multirow{3}{*}{ Традиційна (інтенсивна) } & 2,0 & 0,88 \\
\hline & 2,5 & 1,19 \\
\hline & 3,0 & 0,95 \\
\hline \multirow{3}{*}{ Біологізована } & 2,0 & 1,49 \\
\hline & 2,5 & 1,77 \\
\hline & 3,0 & 1,29 \\
\hline \multirow{3}{*}{ Органічна } & 2,0 & 1,41 \\
\hline & 2,5 & 1,74 \\
\hline & 3,0 & 1,52 \\
\hline \multirow{2}{*}{$\mathrm{HIP}_{05}$, т/га } & часткових відмінностей & $A=0,24, B=0,18$ \\
\hline & головних ефектів & $A=0,28, B=0,33$ \\
\hline
\end{tabular}

2,5 млн шт./га, що забезпечила на тлі традиційної технології отримання 1,19 т/га, біологізованої - 1,77 т/га, органічної - 1,74 т/га кондиційного насіння. У середньому за фрактором В насіннєва продуктивність культури, що вирощувалася за традиційною інтенсивною технологією, становила 0,98 т/га, за біологізованою - 1,52 т/га, за органічною - 1,56 ц/га, що свідчить про перспективність та доцільність залучення до технології вирощування культури як окремих елементів біологізації, так і повного переведення вирощування гірчиці сизої на органічні принципи.

Дещо іншим виявився, за результатами наших досліджень, характер залежності від факторів, що вивчалися, основних якісних показників насіння культури, а саме: вмісту в ньому жирної й ефрірної алілової олії. І якщо істотної залежності між нормою висіву культури й олійністю й ефірністю впродовж двох років дослідження нами не виявлено, то вплив на формування зазначених якісних показників саме технології вирощування був істотним (рис. 1).

Залучення до технології вирощування культури елементів біологізації (заміна мінеральних туків на органічні препарати) дозволило підвищити вміст в гірчичному насінні сирого жиру із 38,6 до $39,3 \%$, а реалізація повної органічної технології вирощування (органічні добрива в комплексі з органічними 33Р) - до 40,4\%. Даний позитивний ефект пояснюється нами, по-перше, відсутністю репелентного впливу органічних пестицидів на медоносних бджіл під час цвітіння гірчиці сарептської, що позначилося на більш активному відвідуванні агроценозу даним видом і покращенні умов запилення; по-друге, більш сприятливими умовами для синтезу жирної олії на фрінальних етапах онтогенезу культури (насамперед через підвищення жаростійкості та посухостійкості рослин під впливом органічних препаратів).

Висновки. Збільшення норми висіву культури з 2,0 до 3,0 млн шт./га зумовлює погіршення значення більшості біометричних показників (висота рослин, облистяність) та всіх показників структури врожаю. Проте, зважаючи на дискретний характер реальної кількості рослин, що збереглися в агроценозі на момент дослідження, значення таких показників, як площа асиміляційного апарату та листковий індекс, а також урожайність кондиційного насіння культури, мали криволінійну залежність: із збільшенням норми висіву від 2,0 до 2,5 млн шт./га зростали, а надалі зменшувалися. Найбільш оптимальною нормою висіву культури за всіх варіантів технології вирощування визнана норма 2,5 млн шт./га. Також у досліді відмічена істотна перевага біологізованої й органічної технології вирощування 


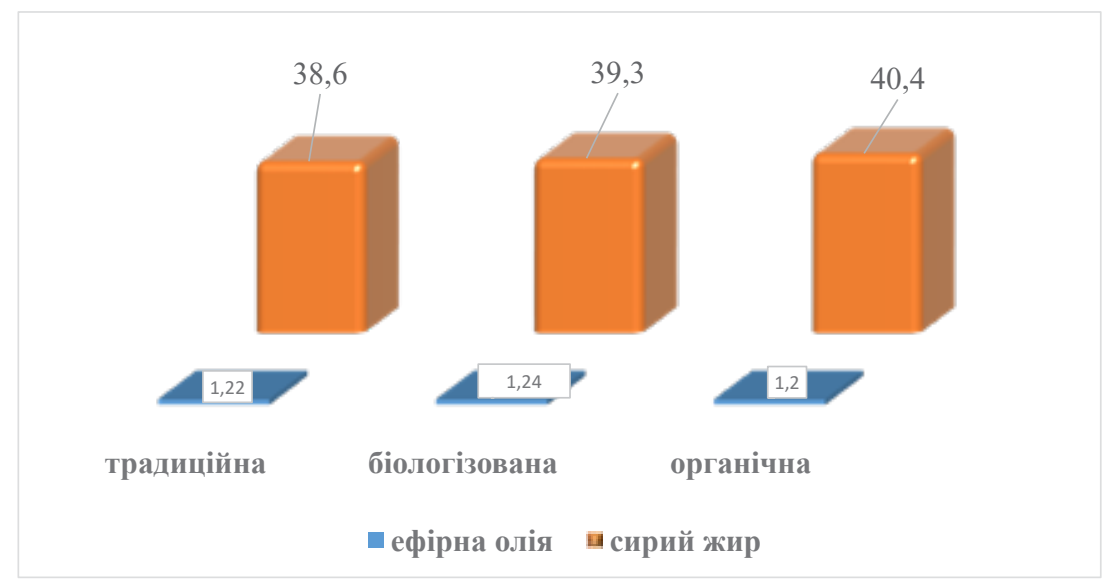

Puc. 1

гірчиці сарептської над традиційною інтенсивною як за біометричними та структурними показниками, так і за рівнем урожайності кондиційного насіння і його якісними показниками, насамперед вмістом у насінні сирого жиру.

\section{СПИСОК ВИКОРИСТАНОÏ ЛІТЕРАТУРИ:}

1. Біологізація землеробства в Україні: реалії та перспективи / за ред. В.В. Іванишина, І.А. Шувара. Івано-Франківськ : Симфоноя форте, 2016. 284 с.

2. Мельник А.В., Жердецька С.В. Стан та перспективи вирощування гірчиці у світі та на Україні. Вісник Сумського національного аграрного університету. Серія «Агрономія $і$ біологія». 2015. Вип. 3 (29). С. 166-169.

3. Наукові основи виробництва органічної продукції в Україні : монографрія / за ред. Я.М. Гадзало, В.Ф. Камінського. Київ : Аграрна наука, 2016. 592 с.

4. Поляков О.І. Особливості формування продуктивності гірчиці ярої під впливом стимуляторів росту за різних способів сівби. Науково-технічний бюлетень Інституту олійних культур Національної академії аграрних наук. 2017. Вип. 24. С. 181-187. URL: http:// nbuv.gov.ua/UJRN/znpiok_2017_24_22.

5. Система удобрення сільськогосподарських культур у землеробстві початку XXI століття / за ред. C.A. Балюка, М.М. Мірошниченка. Київ : Альфра-стевія, 2016. 400 c.

6. Сівак А.Н., Костюкевич Т.К. Перспективи виробництва гірчиці в Україні. Рубіновські читання : матеріали III Всеукраїнської науково-практичної конференції, 14 травня 2021 р., м. Умань С. 18.

\section{REFERENCES:}

1. Biolohizatsiya zemlerobstva $v$ Ukrayini: realiyi ta perspektyvy [Tekst] (2016) / za red. V.V. Ivanyshyna ta I.A. Shuvara. [Biologization of agriculture in Ukraine: realities and prospects], Symfoniya forte [in Ukrainian]

2. Mel'nyk A.V., Zherdets'ka S.V. (2015). Stan ta perspektyvy vyroshchuvannya hirchytsi $v$ sviti ta na Ukrayini [Status and prospects of mustard cultivation in the world and in Ukraine]. Visnyk Sums'koho NAU, № 3 (29), p. 166-169 [in Ukrainian].

3. Naukovi osnovy vyrobnytstva orhanichnoyi produktsiyi $v$ Ukrayini : monohrafiya / za red.
Ya.M. Hadzalo, V.F. Kamins'koho (2016) [Scientific bases of production of organic products in Ukraine], Ahrarna nauka [in Ukrainian].

4. Polyakov O.I. (2017). Osoblyvosti formuvannya produktyvnosti hirchytsi yaroyi pid vplyvom stymulyatoriv rostu za riznykh sposobiv sivby [Features of formation of productivity of spring mustard under the influence of growth stimulators at different methods of sowing]. Naukovo-tekhnichnyi biuleten Instytutu oliinykh kultur NAAN, № 24, p. 181-187 [in Ukrainian].

5. Systema udoskonalennya sil's'kohospodars'kykh kul'tur u zemlerobstvi pochatku XXI stolittya / za red. S.A. Balyuka, M.M. Miroshnychenka (2016) [The system of improvement of agricultural crops in agriculture at the beginning of the XXI century], Alpa-stevia [in Ukrainian].

6. Sivak A.N., Kostyukevich T.K. (2021). Perspektyvy vyrobnytstva hirchytsi v Ukrayini [Prospects for mustard production in Ukraine] Materialy III vseukrainskoi naukovo-praktychnoi konferentsii "Rubinovski chytannia", 14 travnia 2021 r., m. Uman [in Ukrainian].

Жуйков О.Г., Ходос Т.А. Формування комплексу біометричних, структурних і продуктивних показників гірчиці сарептської залежно від норми висіву та рівня біологізації технології вирощування культури в умовах Південного Степу

Метою наукового дослідження було встановлення впливу на комплекс біометричних (висота рослин, площа асиміляційної поверхні, листковий індекс агрофрітоценозу), структурних (елементи пробного снопу, показник $M_{1000}$ ) і продуктивних ознак (урожайність кондиційного насіння, вміст у насінні сирого жиру й ефірної олії) залежно від норми висіву культури та ступеня біологізації технології вирощування культури. Реалізація поставленої мети здійснювалася шляхом закладання польового двофакторного досліду і проведенням комплексу спостережень і лабораторних досліджень. Фактор А (технологія вирощування культури) був представлений варіантами традиційної зональної технології вирощування гірчиці, біологізованою технологією (відмова від мінеральних добрив і заміна їх на органічні препарати) та органічною (заміна мінеральних добрив і синтетичних 33Р на органічні препарати). Фактор В являв собою різні норми висіву культури (від 2,0 до 3,0 мільйонів штук схожих насінин на 1 гектар з інтер- 
валом 0,5 мільйона). У досліді висівався сорт гірчиці Пріма селекції Інституту олійних культур Національної академії аграрних наук. Повторність досліду чотирикратна, загальна площа дослідної ділянки становила 0,9 гектара, загальна площа ділянки першого порядку 250 квадратних метрів, облікова - 200 квадратних метрів. Ділянки в досліді розміщувалися методом розщеплених ділянок із частковою рендомізацією. Збільшення норми висіву культури із 2,0 до 3,0 мільйонів штук на гектар зумовлює погіршення значення більшості біометричних показників (висота рослин, облистяність) та всіх показників структури врожаю. Проте, зважаючи на дискретний характер реальної кількості рослин, що збереглися в агроценозі на момент дослідження, значення таких показників, як площа асиміляційного апарату та листковий індекс, а також врожайність кондиційного насіння культури, мали криволінійну залежність: із збільшенням норми висіву від 2,0 до 2,5 мільйонів штук на гектар зростали, а надалі зменшувалися. Оптимальною нормою висіву культури за всіх варіантів технології вирощування визнана норма 2,5 мільйони штук на гектар. Також у досліді зазначена істотна перевага біологізованої й органічної технології вирощування гірчиці сарептської над традиційною інтенсивною як за біометричними та структурними показниками, так і за рівнем урожайності кондиційного насіння, його якісними показниками, насамперед вмістом у насінні сирого жиру.

Ключові слова: гірчиця сарептська, біологізація, органічна технологія, висота рослин, площа асиміляційного апарату, структура врожаю, урожайність, вміст сирого жиру, ефрірна олія.

Zhuikov O.G., Hodos T.A. Formation of a complex of biometric, structural and productive indicators of Sarepta mustard depending on the sowing rate and the level of biologization of the technology of growing crops in the Southern Steppe

The aim of the study was to establish the impact on the complex of biometric (plant height, assimilation surface area, leaf index of agrophytocenoses), structural (elements of the test sheaf, $\mathrm{M}_{1000}$ ) and productive traits (yield of conditioned seeds, crude fat and essential oil) depending on from the norm of sowing culture and the degree of biologization of culture technology. The realization of this goal was carried out by establishing a two-factor field experiment and conducting a set of observations and laboratory studies. Factor A (culture technology) was represented by variants of traditional zonal technology of mustard cultivation; biologized technology (rejection of mineral fertilizers and their replacement by organic preparations) and organic (replacement of mineral fertilizers and synthetic pesticides by organic preparations). Factor $\mathrm{B}$ was different sowing rates (from 2,0 to 3,0 million pieces of similar seeds per 1 ha with an interval of 0,5 million). The experiment sowed a variety of mustard Prima. The repetition of the experiment is four times, the total area of the experimental plot is 0,9 ha, the total area of the first order plot is $250 \mathrm{~m}^{2}$, the accounting area is $200 \mathrm{~m}^{2}$. The plots in the experiment were placed by the method of split plots with partial randomization. Increasing the sowing rate from 2,0 to 3,0 million units / ha causes a deterioration in the value of most biometric indicators (plant height, foliage) and all indicators of crop structure. However, due to the discrete nature of the actual number of plants preserved in the agrocenosis at the time of the study, the values of such indicators as assimilation apparatus area and leaf index, as well as yield of conditioned seed crops were curvilinear: with increasing seeding rate from 2,0 to 2,5 million units/ ha increased, and further decreased. The norm of 2,5 million units / ha is recognized as the most optimal sowing rate for all variants of cultivation technology. The experiment also noted a significant advantage of biologized and organic technology of growing Sarepta mustard over traditional intensive in terms of biometric and structural indicators, as well as the level of yield of conditioned seeds and its quality indicators, especially crude fat content.

Key words: Sarepta mustard, biologization, organic technology, plant height, assimilation apparatus area, yield structure, yield, crude fat content, essential oil. 